\title{
Current approaches to the management of Her2-negative metastatic breast cancer
}

\author{
Keerthi Gogineni',2 and Angela DeMichele*1-3
}

\begin{abstract}
While metastatic breast cancer (MBC) remains incurable, a vast array of active therapeutic agents has provided the opportunity for long-term disease control while maintaining quality of life and physical function. Optimal management of MBC balances a multitude of factors, including a woman's performance status, social support, symptoms, disease burden, prior therapies, and surrogates for tumor biology. Choosing the most appropriate initial therapy and subsequent sequence of treatments demands flexibility as goals and patient preferences may change. Knowledge of the estrogen receptor (ER), progesterone receptor (PR), and Her2 receptor status of the metastatic tumor has become critical to determining the optimal treatment strategy in the metastatic setting as targeted therapeutic approaches are developed. Patients with $\mathrm{ER}^{+}$or $\mathrm{PR}^{+}$ breast cancer or both have a wide array of hormonal therapy options that can forestall the use of cytotoxic therapies, although rapidly progressive phenotypes and the emergence of resistance may ultimately lead to the need for chemotherapy in this setting. So-called 'triple-negative' breast cancer - lacking ER, PR, and Her2 overexpression - remains a major challenge. These tumors have an aggressive phenotype, and clear targets for therapy have not yet been established. Chemotherapy remains the mainstay of treatment in this group, but biologically based clinical trials of new agents are critical to developing a more effective set of therapies for this patient population.
\end{abstract}

\section{Introduction}

Current management of metastatic breast cancer (MBC) requires nuanced decision-making, synthesizing an array

*Correspondence: angela.demichele@uphs.upenn.edu

'Rena Rowan Breast Center, Abramson Cancer Center, University of Pennsylvania, Perelman Center for Advanced Medicine, West Pavilion, 3rd Floor, 3400 Civic Center Boulevard, Philadelphia, PA 19104, USA

Full list of author information is available at the end of the article of factors, including a patient's goals, performance status, comorbidities, the burden and pace of disease, tumor subtype, and exposure to prior therapies. Despite an ever-expanding armamentarium of cytotoxics, endocrine therapies, biologics, and small-molecule inhibitors, only $25 \%$ of white women and $15 \%$ of black women with MBC diagnosed between 2001 and 2008 survived 5 years [1]. The following review focuses on systemic management of Her2-negative MBC organized by disease subtype. In cases of locally recurrent disease or isolated distant metastasis, site- or organ-specific therapy and palliation may take precedence over systemic strategies. Figure 1 shows the current treatment paradigm for $\mathrm{MBC}$ on the basis of receptor status and key considerations guiding therapeutic decision-making within each group.

Metastatic involvement may be identified through standard baseline radiologic staging at the time of diagnosis of the incident breast cancer, baseline or subsequent abnormalities in laboratory indices, or evaluation of focal symptoms such as persistent shortness of breath, cough, abdominal pain, nausea, bone pain, or neurologic changes. In the absence of focal symptoms, the American Society of Clinical Oncology (ASCO) and clinical practice guidelines produced by the National Comprehensive Cancer Network maintain that imaging of bone, chest, abdomen, and pelvis is, at best, based on lower-level evidence without expert consensus [2,3]. Similarly, the use of serum tumor markers and commercially available circulating tumor cell assays to detect recurrence after primary therapy is not recommended outside of a clinical trial [4]. ASCO does recognize the potential utility of serum tumor markers to assist in monitoring patients on therapy for metastatic disease.

Given the potential for discordance between the receptor status of the primary and metachronous metastases, biopsy of metastatic disease at the time of recurrence should be strongly considered not only to confirm the diagnosis but also to inform potential benefit of targeted therapies such as endocrine therapy or Her2targeted therapies or both. However, reported rates of discordance ranging from $10 \%$ to $40 \%$ may variably reflect a true change in tumor biology, sampling error, or assay error [5]. Validated chemosensitivity or resistance 


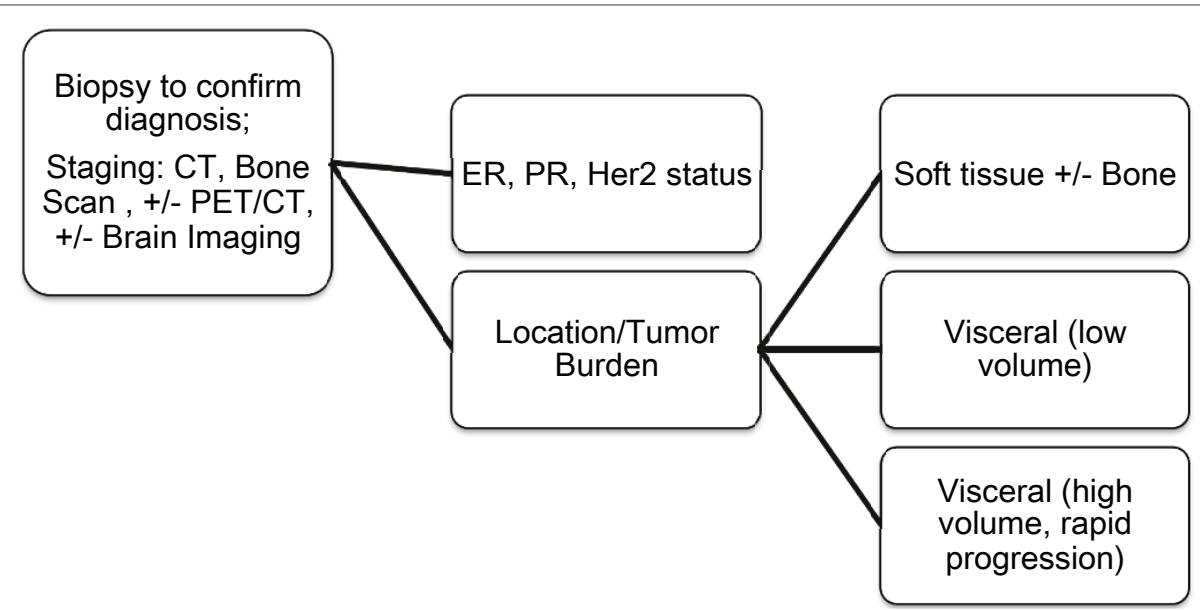

Figure 1. Approach to the patient with metastatic breast cancer. CT, computed tomography; ER, estrogen receptor; PET, positron emission tomography; PR, progesterone receptor.

assays to predict response to individual cytotoxics remain elusive tools, and this is due in part to technical limitations, sampling challenges, complex interactions between the host, tumor, and tumor microenvironment, and limited data demonstrating that in vitro results correlate to clinical outcomes [6]. Thus, at present, clinicians must optimize treatment strategies combining existing knowledge of the dominant tumor phenotype, interval from and type of prior regimens, patient's preferences, and performance status while assessing the need for rapid response in the face of a visceral threat.

\section{Hormone-sensitive metastatic breast cancer}

Two thirds of women with diagnosed breast cancer have disease that is estrogen receptor/progesterone receptorpositive $\left(\mathrm{ER} / \mathrm{PR}^{+}\right)$[7]. These tumors are highly responsive to anti-estrogen therapeutic strategies. However, despite widespread use of hormonal adjuvant therapy, a quarter of women with $\mathrm{ER}^{+}$disease will relapse [8]. In this situation, a determination regarding further hormonal therapy versus chemotherapy as the next step must be made. Patients whose disease is viscerally relatively 'low'volume, bone/soft tissue-predominant, and asymptomatic are reasonable candidates for upfront endocrine therapy. Figure 2 outlines the therapeutic approach to women with $\mathrm{ER}^{+}$, hormone-sensitive disease, and the evidence supporting these treatment strategies is outlined below and in Table 1 . Of note, many of the earlier but pivotal studies included patients whose receptor status was unknown, thereby potentially underestimating the effects of endocrine blockade.

\section{Tamoxifen, fulvestrant, and ovarian suppression}

Tamoxifen emerged as a non-surgical alternative for the management of $\mathrm{ER}^{+} \mathrm{MBC}$ in the late 1970s. A non-steroidal selective estrogen receptor modulator (SERM) whose primary effect is to competitively inhibit the binding of estradiol to ERs, tamoxifen prevents the receptor from binding to the estrogen-response element on DNA. However, it also induces elevated estradiol levels via a partial agonist effect [9] that can be suppressed to normal postmenopausal levels by gonadotropin-releasing hormone $(\mathrm{GnRH})$ agonists. Studies comparing tamoxifen with oopherectomy among premenopausal women with $\mathrm{MBC}$ found no significant difference in overall response rate (RR), duration of response, time to progression (TTP), or survival, nor was there a significant difference in outcomes when GnRH agonists were compared with oopherectomy [10,11].

Complete estrogen blockade in premenopausal women can be achieved by using combination therapy and is analogous to the principle of total androgen blockade in prostate cancer. Meta-analysis has confirmed that the combination of GnRH agonists plus tamoxifen affords a superior progression-free survival (PFS) and overall survival (OS) compared with luteinizing hormone release hormone agonists alone in the treatment of premenopausal women with $\mathrm{ER} / \mathrm{PR}^{+} \mathrm{MBC}[12]$.

The current practice for premenopausal women with MBC previously unexposed to hormone blockade is to be treated in the first-line setting with tamoxifen as initial endocrine therapy or with aromatase inhibitor (AI) therapy in combination with ovarian suppression (via oopherectomy, radiation, or a GnRH agonist). Ovarian radiation is a less optimal mode of ablation as the success rate and time to ablation vary compared with irreversible and immediate ablation afforded by oopherectomy. An Eastern Cooperative Oncology Group study examining adjuvant estrogen blockade in premenopausal patients randomly assigned patients to tamoxifen monotherapy 


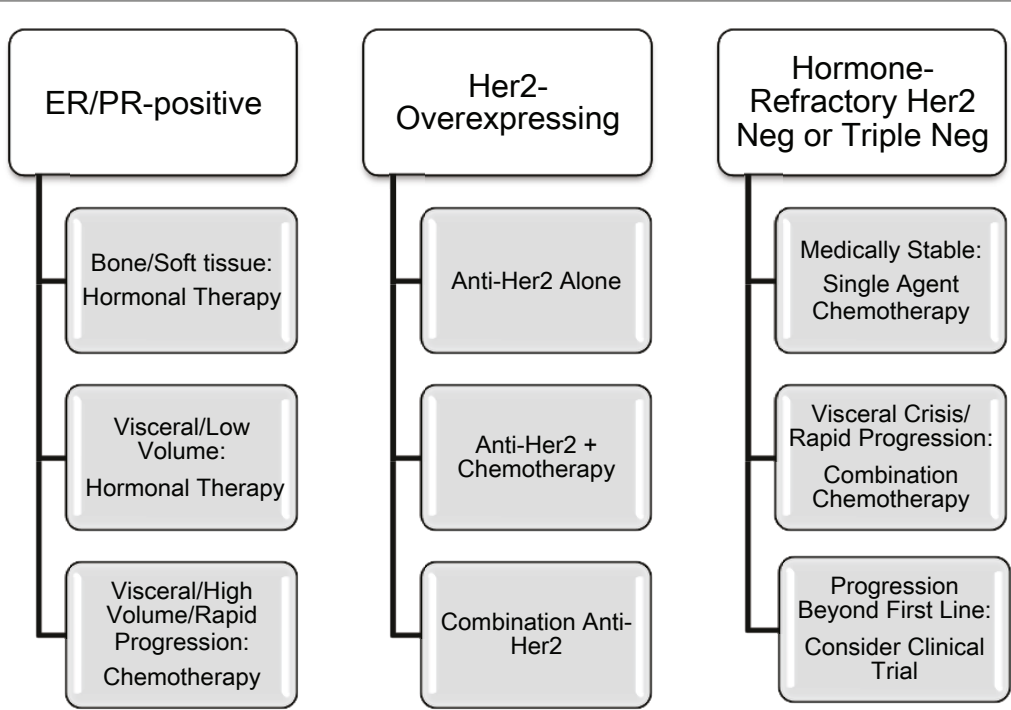

Figure 2. Therapeutic approach based on subtype and sensitivity. ER, estrogen receptor; Her2 Neg, Her2-negative; PR, progesterone receptor; Triple Neg, triple-negative.

versus tamoxifen plus ovarian ablation via radiotherapy, oopherectomy, or GnRH agonists [13]. The trial was closed early for inadequate accrual; however, $75 \%$ of those undergoing radiotherapy achieved estradiol or follicle-stimulating hormone (FSH) levels consistent with those of ovarian ablation at 6 months after completing 20 Gy in 10 fractions. Further evidence supporting the need for ovarian suppression in addition to tamoxifen is lacking; data pertaining to premenopausal women in the adjuvant setting suggest that the combination of goserelin and tamoxifen is not superior to tamoxifen alone [14]. Responses to surgical castration have been observed after tamoxifen failures, and oopherectomy should be considered if a premenopausal woman relapses after adjuvant or first-line tamoxifen in the metastatic setting.

Fulvestrant (Faslodex; AstraZeneca, London, UK) is a synthetic ER antagonist that downregulates and degrades ERs by competitively binding them without tamoxifen's partial agonist effect [9]. Intramuscular injections of fulvestrant were compared with tamoxifen in a large randomized trial to ascertain whether the absence of partial agonist properties of fulvestrant conferred better outcomes among postmenopausal women with MBC. Despite the lack of first-line superiority over tamoxifen, the NCCTG (North Central Cancer Treatment Group) N0032 and CONFIRM (Comparison of Faslodex in Recurrent or Metastatic Breast Cancer) trials demonstrated that fulvestrant has efficacy as sequential endocrine therapy in postmenopausal women in the second- and even third-line setting $[15,16]$. The latter study also established the current standard dose of fulvestrant at $500 \mathrm{mg}$ monthly given the superior efficacy compared with $250 \mathrm{mg}$ monthly [15]. Subsequently, the
FIRST (Fulvestrant First-line Study Comparing Endocrine Treatments) trial, a phase II study that randomly assigned women who were endocrine therapynaïve to fulvestrant (500 mg monthly) versus anastrozole (1 mg daily), showed a comparable clinical benefit rate (CBR) and a longer TTP for fulvestrant, suggesting the potential for an alternate first-line endocrine agent to AIs in postmenopausal women [17].

\section{Aromatase inhibitors: exemestane, anastrozole, and letrozole}

Estrogen production in postmenopausal women is derived from the peripheral aromatization of androgens. Inhibition of aromatase is thereby a cornerstone of hormonal blockade in the management of postmenopausal breast cancer [18]. These drugs cannot be used alone safely in premenopausal women without concomitant ovarian suppression or ablation since aromatase inhibition in the setting of functional ovaries will lead to ovarian hyperstimulation [19]. AIs currently in use include anastrozole (Arimidex; AstraZeneca), letrozole (Femara; Novartis, East Hanover, NJ, USA), and exemestane (Aromasin; Pfizer Inc, New York, NY, USA). Analysis of two large randomized trials in which postmenopausal women who were endocrine therapy-naïve in the metastatic setting showed that anastrozole was at least equivalent to tamoxifen in the first-line setting; unplanned subgroup analysis restricted to patients with known positive hormone receptors demonstrated a superior TTP for anastrozole [20]. Letrozole has also been directly compared with tamoxifen in the first-line setting among women with MBC and similarly increased the TTP [21]. As such, anastrozole and letrozole, non-steroidal AIs, are first-line endocrine options in postmenopausal MBC. 
Table 1. Selected studies of endocrine therapy in metastatic breast cancer

\begin{tabular}{|c|c|c|c|c|}
\hline Phase & Drug/Regimen & $\begin{array}{c}\text { Line of } \\
\text { endocrine therapy }\end{array}$ & $\begin{array}{l}\text { Number (percentage } \\
\text { of HR unknown) }\end{array}$ & Findings \\
\hline\|\|$^{\mathrm{a}}$ & $\begin{array}{l}\text { Tamoxifen } \\
\text { POA 74181/74185 [77] }\end{array}$ & 1st line & $\begin{array}{l}156 \text { premenopausal }+ \\
\text { postmenopausal (24\%) }\end{array}$ & $\begin{array}{l}\text { RR: } 16 \% \\
\text { TTP: } 6.7 \text { months } \\
\text { 5-year PFS: } 8 \% \\
\text { OS: } 27.2 \text { months }\end{array}$ \\
\hline III & Tamoxifen vs. BSO [10] & 1st line & 53 premenopausal (21\%) & $\begin{array}{l}\text { CR: } 0 \% \text { vs. } 15 \% \\
\text { PR: } 31 \% \text { vs. } 20 \% \\
\text { TTP: } 160 \text { vs. } 144 \text { days } \\
\text { OS: } 749 \text { vs. } 722 \text { days }\end{array}$ \\
\hline III & $\begin{array}{l}\text { BSO/RT vs. goserelin vs. BSO/RT + tamoxifen vs. } \\
\text { tamoxifen + goserelin [11] }\end{array}$ & 1st line & 85 perimenopausal (33\%) & $\begin{array}{l}\text { RR: } 47 \% \text { vs. } 27 \% \text { vs. } 11 \% \text { vs. } 45 \% \\
\text { OS: } 37 \text { (ovarian) vs. } 36 \text { months (goserelin) }\end{array}$ \\
\hline III & $\begin{array}{l}\text { Buserelin vs. tamoxifen vs. buserelin + tamoxifen } \\
\text { EORTC } 10881 \text { [78] }\end{array}$ & 1st line & 161 premenopausal (52\%) & $\begin{array}{l}\text { RR: } 34 \% \text { vs. } 28 \% \text { vs. } 48 \% \\
\text { PFS: } 6.3 \text { vs. } 5.6 \text { months. vs. } 9.7 \text { months }^{b} \\
\text { OS: } 2.5 \text { vs. } 2.9 \text { vs. } 3.7 \text { years }\end{array}$ \\
\hline Meta & LHRH agonist vs. LHRH + tamoxifen [12] & 1st line & 506 premenopausal (22\%) & $\begin{array}{l}\text { RR: } 30 \% \text { vs. } 39 \%^{b} \\
\text { PFS HR: } 0.70^{b} \\
\text { OS HR: } 0.78^{b}\end{array}$ \\
\hline III & $\begin{array}{l}\text { Fulvestrant } 500 \text { mg every } 30 \text { days vs. fulvestrant } \\
250 \text { mg every } 30 \text { days } \\
\text { CONFIRM [15] }\end{array}$ & 1st/2nd line & 736 postmenopausal & $\begin{array}{l}\text { RR: } 9 \% \text { vs. } 10 \% \\
\text { PFS HR: } 0.80^{\mathrm{b}} \\
\text { OS: } 25.1 \text { vs. } 22.8 \text { months }\end{array}$ \\
\hline III & $\begin{array}{l}\text { Fulvestrant } 250 \text { mg every } 30 \text { days vs. tamoxifen } \\
20 \text { mg by mouth every day [79] }\end{array}$ & 1st line & 587 postmenopausal (20\%) & $\begin{array}{l}\text { RR: } 33 \% \text { vs. } 31 \% \\
\text { TTP: } 8.2 \text { vs. } 8.3 \text { (estrogen receptor/ } \\
\text { progesterone receptor-positive) } \\
\text { OS: } 39.3 \text { vs. } 40.7 \text { months }\end{array}$ \\
\hline III & $\begin{array}{l}\text { Fulvestrant vs. anastrozole } \\
\text { FIRST [17] }\end{array}$ & 1st line & 205 postmenopausal & $\begin{array}{l}\text { CBR: } 73 \% \text { vs. } 67 \% \\
\text { TTP: not reached vs. } 12.5 \text { months }^{b}\end{array}$ \\
\hline III & $\begin{array}{l}\text { Anastrozole } \rightarrow \text { tamoxifen vs. tamoxifen } \rightarrow \text { anastrozole } \\
\text { TARGET/SAKK 21/95 [80] }\end{array}$ & 1st line & 60 postmenopausal (20\%) & $\begin{array}{l}\text { TTP: } 28.2 \text { vs. } 19.5 \text { months }^{c} \\
\text { OS: } 69.7 \text { vs. } 59.3 \text { months }\end{array}$ \\
\hline III & $\begin{array}{l}\text { Letrozole vs. tamoxifen } \\
\text { LILBCG [81] }\end{array}$ & 1st line & 977 postmenopausal & TTP: 42 vs. 21 weeks \\
\hline III & Exemestane vs. megestrol [23] & 1st line & 769 postmenopausal & $\begin{array}{l}\text { TTP: } 20 \text { vs. } 17 \text { weeks }{ }^{b} \\
\text { OS: not reached vs. } 123.4 \text { weeks }^{b}\end{array}$ \\
\hline III & $\begin{array}{l}\text { Exemestane vs. tamoxifen } \\
\text { EORTC [22] }\end{array}$ & 1st line & 371 postmenopausal (6.5\%) & $\begin{array}{l}\text { RR: } 46 \% \text { vs. } 31 \%^{\mathrm{b}} \\
\text { PFS: } 9.9 \text { vs. } 5.8 \text { months }^{\mathrm{b}} \text { but NS after } \\
47 \text { months follow-up } \\
\text { OS HR: } 1.13\end{array}$ \\
\hline III & Anastrozole vs. exemestane [24] & 1st line & 130 postmenopausal & $\begin{array}{l}\text { Insufficient accrual } \\
\text { RR: } 16 \% \text { vs. } 16 \% \\
\text { TTP: } 3.71 \text { vs. } 4.24 \text { months } \\
\text { OS: } 33.3 \text { vs. } 30.5 \text { months }\end{array}$ \\
\hline$\|$ & Megestrol [25] & 2nd line & 73 & $\begin{array}{l}\text { CR: } 0 \% \\
\text { PR: } 4 \% \text { for median of } 9 \text { months } \\
\text { Median } 8 \text { months of stabilization in } 48 \%\end{array}$ \\
\hline III & $\begin{array}{l}\text { Tamoxifen vs. megestrol } \\
\text { POA [82] }\end{array}$ & 1st line & $\begin{array}{l}182 \text { premenopausal + } \\
\text { postmenopausal (17\%) }\end{array}$ & $\begin{array}{l}\text { RR: } 17 \% \text { vs. } 34 \%^{\mathrm{b}} \\
\text { TTF: } 5.5 \text { vs. } 6.3 \text { months } \\
\text { OS: } 23.8 \text { vs. } 33 \text { months }\end{array}$ \\
\hline III & Vorozole vs. megestrol [18] & 1st/2nd line & 452 postmenopausal (15\%) & $\begin{array}{l}\text { RR: } 10 \% \text { vs. } 7 \% \\
\text { Duration response: } 18.2 \text { vs. } 12.5 \text { months } \\
\text { TTP: } 2.6 \text { vs. } 3.3 \text { months } \\
\text { OS: } 26.3 \text { vs. } 28.8 \text { months }\end{array}$ \\
\hline$\|$ & $\begin{array}{l}\text { Estradiol } 30 \mathrm{mg} \text { by mouth every day vs. estradiol } \\
6 \mathrm{mg} \text { by mouth every day [26] }\end{array}$ & 1st/2nd line & 66 postmenopausal & CBR: $28 \%$ vs. $29 \%$ \\
\hline
\end{tabular}

aNon-randomized phase III. bStatistically significant. cNo formal statistical comparison as this was not a preplanned analysis. BSO, bilateral salpingo-oophorectomy; CBR, clinical benefit rate; CONFIRM, Comparison of Faslodex in Recurrent or Metastatic Breast Cancer; CR, complete response; EORTC, European Organisation for Research and Treatment of Cancer; FIRST, Fulvestrant First-line Study Comparing Endocrine Treatments; HR, hormone receptor; LHRH, luteinizing hormone-releasing hormone; LILBCG, Letrozole International Letrozole Breast Cancer Group; NS, not significant; OS, overall survival; PFS, progression-free survival; POA, Piedmont Oncology Association; PR, partial response; RR, response rate; RT, radiotherapy; TARGET/SAKK, Tamoxifen or 'Arimidex' Randomized Group Efficacy and Tolerability/ Swiss Group for Clinical Cancer Research; TTF, time to treatment failure; TTP, time to progression. 
Exemestane, unlike the non-steroidals in this class, is a steroidal AI that irreversibly inhibits aromatase. In women who have progressed on tamoxifen, exemestane showed prolonged TTP and OS compared with megestrol $[22,23]$. In addition to having a utility in the second-line setting, exemestane showed significant early improvement in TTP compared with tamoxifen in the first-line setting, although after longer follow-up, the two drugs were found to have comparable efficacy [22]. There is a paucity of data comparing AIs directly to each other in the metastatic setting; however, extrapolation from a small trial showed that exemestane and anastrozole had similar RRs among postmenopausal women who had $\mathrm{MBC}$ and who were tamoxifen-refractory [24].

\section{Progestins: megestrol}

Progestins, such as megestrol acetate (MA), are some of the oldest compounds to be used in the treatment of $\mathrm{MBC}$, indirectly reducing serum estrogen levels by reducing androgen levels [9]. While use of these agents has dropped dramatically since the introduction of AIs and GNRH agonists, there are data demonstrating the efficacy of these agents in the MBC setting. Although randomized trials comparing $\mathrm{MA}$ and tamoxifen show comparable RRs and TTP, ultimately tamoxifen remains preferable to MA because of the toxicity profile. Analyses comparing AI and MA have shown that anastrozole confers a survival advantage over MA, and letrozole shows an improved RR and time to treatment failure [18]. After failure on first- and second-line therapies, data suggest that the use of MA as a second- or third-line therapy is reasonable primarily for 'durable' disease stabilization but not with the goal of response [25].

\section{Paradoxical estrogen sensitization: estradiol}

The development of estrogen sensitization in breast cancer cells after long-term estrogen deprivation paradoxically enables treatment with low-dose estradiol that in some cases confers re-sensitization to subsequent retreatment with an AI. Women with ER/PR ${ }^{+}$AI-resistant metastatic disease were randomly assigned to $30 \mathrm{mg}$ daily of estradiol or $6 \mathrm{mg}$ daily to assess CBR in the low-dose versus higher-dose group [26]. AI resistance was defined as relapse within 2 years after adjuvant AI or prior treatment within the metastatic setting. Study participants who had been exposed to fulvestrant within the previous 12 months were excluded because of data showing in vitro antagonism of estrogen-induced apoptosis. There was no significant difference in the CBR between the two groups, and re-treatment with the last AI used in the responders showed clinical benefit in three of the seven patients re-treated.

\section{Hormone receptor-positive, endocrine-refractory metastatic breast cancer: mTOR inhibition}

The development of hormone resistance in $\mathrm{ER}^{+}$but endocrine-refractory metastatic disease is postulated to involve signal transduction pathways, including mammalian target of rapamycin (mTOR). Results from a second-line phase II study randomly assigning patients with hormone-positive MBC to tamoxifen versus tamoxifen plus an mTOR inhibitor (everolimus) showed a significant improvement in the CBR, median TTP, and OS as of a September 2011 update at the European Multidisciplinary Cancer Congress [27,28]. The PI3K/Akt/ mTOR pathway is constitutively activated in AI-resistant breast cancer. Results of the phase III randomized controlled trial BOLERO-2 (Breast Cancer Trials of Oral Everolimus-2), updated at the San Antonio Breast Cancer Symposium in December 2011, showed that postmenopausal women refractory to letrozole or anastrozole treated with a combination of everolimus and exemestane had an improved PFS of 10.6 months compared with 4.1 months in women treated with exemestane alone [7]. This combination has the potential to delay initiation of cytotoxic therapy in endocrine-refractory patients.

In summary, first-line endocrine therapy is preferred for women whose hormone receptor-positive $\mathrm{MBC}$ is limited to bone or soft tissue or both and for those whose visceral volume of disease does not appear to be fastgrowing or pose imminent threat of organ compromise. After failure of first-line endocrine therapy, sequential endocrine options are preferable to cytotoxic therapy provided that metastatic sites are still hormone receptorpositive. Premenopausal women who are endocrinenaïve should receive tamoxifen and, in the second-line setting, can undergo ovarian suppression via either surgical or chemical castration and then an AI. Postmenopausal women should be offered an AI as first-line treatment of their metastatic disease. After progression on an AI, subsequent therapy could consist of sequential endocrine options, including an alternative AI (that is, steroidal if the first AI was non-steroidal), tamoxifen, or fulvestrant. Megestrol should be reserved for use after failure on first- and second-line therapies. Estradiol can be considered if the volume of disease permits an attempt at re-sensitization to an AI. Ultimately, postmenopausal patients who progress after a non-steroidal AI may be treated with the combination of everolimus and exemestane provided that everolimus receives US Food and Drug Administration (FDA) approval for this indication. In the clinical scenario of hormone-sensitive disease that is rapidly progressive and threatening organ function, cytotoxic therapy can be considered with the goal of resumption of an endocrine agent if visceral crisis has abated rather than empirically persisting with a series of cytotoxic therapies. 


\section{Treatment of metastatic breast cancer that is $\mathrm{ER}^{+}$/ endocrine-refractory or triple-negative or that presents with visceral threat}

Admittedly, using receptor status and sensitivity to guide management of therapy in MBC oversimplifies the discrete molecular subtypes identified through advances in genomic analysis. For example, the biologic behavior and drivers of an $\mathrm{ER}^{+}$luminal breast cancer that becomes hormone-insensitive are presumably distinct from those of triple-negative basal-like subtypes, as evidenced by different patterns of relapse and response to treatment [29]. However, practically speaking, molecular subtyping is not available as a routine clinical test, nor were tumors prospectively subtyped in the clinical trials that led to FDA approval for these drugs in MBC. With this limitation in mind, Figure 2 outlines the therapeutic approach to women with $\mathrm{ER}^{+}$, hormone-refractory or 'triplenegative' $\mathrm{MBC}$; the evidence supporting these treatment strategies is listed in Table 2 and discussed briefly below. A guiding principle of treatment of metastatic disease is to respect the palliative goal of this therapy given the absence of data demonstrating superior survival benefit with combination cytotoxics rather than sequential strategies. Sequential administration of single agents has been considered a viable and acceptable standard of care and this is due, in part, to Intergroup trial E1193, in which, despite increased RR and time to treatment failure (primary outcomes the trial was designed to detect) with combination paclitaxel and doxorubicin in metastatic disease, sequential doxorubicin followed by paclitaxel and vice versa showed similar efficacy and no difference in survival benefit [8]. Many patients will require multiple lines of therapy for advanced disease, and, as such, use of combination chemotherapy regimens rather than sequential use of single-agent cytotoxics should be limited to specific circumstances in which performance status permits it and rapid response is critical, as with impending organ failure. Table 2 and the following discussion review RRs of single-agent cytotoxics and also expected responses to combination regimens that have a particular synergy. Cytotoxics that have FDA-approved indications in $\mathrm{MBC}$ and that have activity as single agents include anthracyclines, taxanes, non-taxane microtubule inhibitors, and antimetabolites.

Anthracycline single-agent cytotoxic therapy: doxorubicin, epirubicin, and pegylated liposomal doxorubicin

Many patients will have been exposed to anthracyclines in the adjuvant setting; however, with the advent of docetaxel/cyclophosphamide as a standard adjuvant doublet, more patients may present with recurrent disease without having been exposed to these agents. Women with metastatic disease (receptor status not reported) exposed to alkylators in the adjuvant setting or to, at most, one line of therapy in the advanced setting or to both were randomly assigned to doxorubicin $75 \mathrm{mg} / \mathrm{m}^{2}$ versus docetaxel $100 \mathrm{mg} / \mathrm{m}^{2}$ every 3 weeks. Although docetaxel resulted in a higher objective $R R$ in this pretreated population with visceral disease, there was no statistically significant difference in median TTP or OS. Neutropenic fever, infection, cardiac toxicity, nausea, and vomiting were more likely with anthracycline therapy, whereas the primary toxicities caused by docetaxel consisted of diarrhea, neuropathy, fluid retention, and skin and nail changes [30]. In a trial designed to establish the optimal dose of first-line epirubicin in $\mathrm{MBC}$, women who had mostly positive/unknown hormone receptor status and whose adjuvant regimens were nonanthracycline-based were randomly assigned to four dose levels of epirubicin, including $90 \mathrm{mg} / \mathrm{m}^{2}$, which is hematologically equivalent to the maximum tolerated dose of $75 \mathrm{mg} / \mathrm{m}^{2}$ of doxorubicin. This dose was found to afford the greatest TTP at the least toxicity and is further evidence that single-agent anthracyclines have efficacy [31]. Pegylated liposomal doxorubicin (PLD) has also been examined in the hope that preferential accumulation in tumor tissue would limit cardiotoxicity. In a noninferiority trial designed to assess efficacy and cardiac safety, women who could have received prior adjuvant anthracycline were randomly assigned to either PLD or doxorubicin. Non-inferiority was achieved; however, not surprisingly, significantly more doxorubicin-treated patients met the protocol-defined criteria for cardiotoxicity [32].

\section{Taxane single-agent cytotoxic therapy: paclitaxel and docetaxel}

Single-agent taxanes are an effective option in metastatic patients, particularly in those who were treated with only anthracycline-based adjuvant therapy. Taxanes induce mitotic arrest by inhibiting depolymerization of the microtubules. Although the mechanism of paclitaxel and docetaxel of binding to tubulin and cell cycle arrest through stabilization of microtubules is similar, preclinical studies have shown that docetaxel has greater affinity, longer retention time, and higher intracellular concentration in target cells [33]. Side effect profiles are also different as fluid retention and fatigue are more characteristic of docetaxel toxicity whereas hypersensitivity and neurotoxicity are more common with paclitaxel. This difference is thought to be related to the solvents required for stabilization of these hydrophobic compounds. Several studies have examined optimal dosing regimens of taxanes. Weekly paclitaxel appears to be as effective as or more effective than every-21-day dosing $[34,35]$. Docetaxel administered every 3 weeks has better efficacy compared with either weekly or every3-week paclitaxel but at the expense of more toxicity $[33,36]$. Docetaxel on a weekly schedule still results in 
Table 2. Selected studies of single-agent and synergistic combination cytotoxic therapies in estrogen receptor-positive, endocrine-refractory, or triple-negative metastatic breast cancer

\begin{tabular}{|c|c|c|c|c|}
\hline Phase & Drug/Regimen & Line of therapy & Number & Findings \\
\hline$\|$ & Epirubicin 135 vs. 90 vs. 60 vs. 40 mg/m² [31] & +/- endocrine & 287 & $\begin{array}{l}\text { RR: } 37 \% \text { (90 or } 135) \\
\text { TTP: } 8.4 \text { (90) vs. } 4.4 \text { months }(40)^{\text {a }}\end{array}$ \\
\hline III & $\begin{array}{l}\text { Doxorubicin } 60 \mathrm{mg} / \mathrm{m}^{2} \text { every } 3 \text { weeks vs. liposomal doxorubicin } \\
50 \mathrm{mg} / \mathrm{m}^{2} \text { every } 3 \text { weeks CAELYX [32] }\end{array}$ & $\begin{array}{l}+/ \text { - adjuvant anthracycline } \\
\text { or endocrine }\end{array}$ & 509 & $\begin{array}{l}\text { PFS: } 7.8 \text { vs. } 6.9 \text { months } \\
\text { OS: } 22 \text { vs. } 21 \text { months }\end{array}$ \\
\hline III & $\begin{array}{l}\text { Doxorubicin } 75 \mathrm{~m} / \mathrm{m}^{2} \text { every } 3 \text { weeks vs. docetaxel } 100 \mathrm{mg} / \mathrm{m}^{2} \\
\text { every } 3 \text { weeks [30] }\end{array}$ & Prior alkylator & 326 & $\begin{array}{l}\text { RR: } 33 \% \text { vs. } 48 \%^{\mathrm{a}} \\
\text { TTP: } 21 \text { vs. } 26 \text { weeks } \\
\text { OS: } 14 \text { vs. } 15 \text { months }\end{array}$ \\
\hline$\|$ & Docetaxel $40 \mathrm{mg} / \mathrm{m}^{2}$ every week, 6 weeks, every 8 weeks [37] & 1st/2nd line & 29 & $\begin{array}{l}\text { RR: } 41 \% \\
\text { CBR: } 59\end{array}$ \\
\hline$\|$ & Paclitaxel $80 \mathrm{mg} / \mathrm{m}^{2}$ every week & $\begin{array}{l}\text { Prior anthracycline } \\
+/- \text { every } 3 \text { weeks taxane }\end{array}$ & 212 & $\begin{array}{l}\text { RR: } 22 \% \\
\text { TTP: } 4.7 \text { months } \\
\text { OS: } 12.8 \text { months }\end{array}$ \\
\hline$\|$ & $\begin{array}{l}\text { Paclitaxel } 250 \mathrm{mg} / \mathrm{m}^{2} \text { every } 3 \text { weeks vs. } 175 \mathrm{mg} / \mathrm{m}^{2} \text { every } \\
3 \text { weeks [83] }\end{array}$ & 1st/2nd line & 49 & RR: $32 \%$ vs. $21 \%$ \\
\hline III & $\begin{array}{l}\text { Docetaxel } 100 \mathrm{mg} / \mathrm{m}^{2} \text { every } 3 \text { weeks vs. paclitaxel } 175 \mathrm{mg} / \mathrm{m}^{2} \\
\text { every } 3 \text { weeks [33] }\end{array}$ & 1st/2nd line & 449 & $\begin{array}{l}\text { TTP: } 5.7 \text { vs. } 3.6 \text { months }^{\mathrm{a}} \\
\text { OS: } 15.4 \text { vs. } 12.7 \text { months }^{\mathrm{a}}\end{array}$ \\
\hline III & $\begin{array}{l}\text { Nab-paclitaxel } 260 \mathrm{mg} / \mathrm{m}^{2} \text { every } 3 \text { weeks vs. paclitaxel } \\
175 \mathrm{mg} / \mathrm{m}^{2} \text { every } 3 \text { weeks [38] }\end{array}$ & $\begin{array}{l}\text { Unlimited; no prior taxane } \\
\text { in metastatic setting }\end{array}$ & 225 & $\begin{array}{l}\text { RR: } 33 \% \text { vs. } 19 \%^{\mathrm{a}} \\
\text { TTP: } 23 \text { vs. } 16.9 \text { weeks }^{\mathrm{a}} \\
\text { OS: } 60.5 \text { vs. } 55.7 \text { weeks }\end{array}$ \\
\hline$\|$ & $\begin{array}{l}\text { Nab-paclitaxel } 300 \text { every } 3 \text { weeks or } 100 \text { every week or } 150 \mathrm{mg} / \mathrm{m}^{2} \\
\text { every week vs. docetaxel } 100 \mathrm{mg} / \mathrm{m}^{2} \text { every } 3 \text { weeks [39] }\end{array}$ & 1st line & 302 & $\begin{array}{l}\text { RR: } 49 \% \text { (150) vs. } 45 \% \text { (100) vs. } 35 \% \text { (d) } \\
\text { PFS: } 13 \text { (150) vs. } 7.5 \text { months (d) }{ }^{\text {a }}\end{array}$ \\
\hline III & $\begin{array}{l}\text { Docetaxel } 100 \mathrm{mg} / \mathrm{m}^{2} \text { every } 3 \text { weeks vs. capecitabine } 1,250 \mathrm{mg} / \mathrm{m}^{2} \\
\text { twice a day } \times 14 \text { days every } 3 \text { weeks }+ \text { docetaxel } 75 \mathrm{mg} / \mathrm{m}^{2} \\
\text { every } 3 \text { weeks [50] }\end{array}$ & 1st/2nd line & 511 & $\begin{array}{l}\text { RR: } 30 \% \text { vs. } 42 \%^{\mathrm{a}} \\
\text { TTP: } 6.1 \text { vs. } 4.2 \text { months }^{\mathrm{a}} \\
\text { OS: } 14.5 \text { vs. } 11.5 \text { months }^{\mathrm{a}}\end{array}$ \\
\hline III & $\begin{array}{l}\text { Paclitaxel } 175 \mathrm{~g} / \mathrm{m}^{2} \text { every } 3 \text { weeks vs. paclitaxel } 175 \mathrm{~g} / \mathrm{m}^{2} \\
\text { every } 3 \text { weeks }+ \text { gemcitabine } 1,250 \mathrm{mg} / \mathrm{m}^{2} \mathrm{D} 1 \text { and D } 8 \\
\text { every } 3 \text { weeks [54] }\end{array}$ & 1st line & 529 & $\begin{array}{l}\text { RR: } 41 \% \text { vs. } 26 \%^{\mathrm{a}} \\
\text { TTP: } 6.14 \text { vs. } 3.98 \text { months }^{\mathrm{a}} \\
\text { OS: } 18.6 \text { vs. } 15.8 \text { months }^{\mathrm{a}}\end{array}$ \\
\hline$\|$ & Vinorelbine $35-30$ mg/m² every week [40] & $\begin{array}{l}\text { 2nd/3rd line; anthracycline } \\
+/- \text { taxane }\end{array}$ & 40 & $\begin{array}{l}\text { RR: } 25 \% \\
\text { TTF: } 6 \text { months } \\
\text { OS: } 6 \text { months }\end{array}$ \\
\hline$\|$ & Ixabepilone 40 mg/m² every 3 weeks [41] & 1st line & 65 & $\begin{array}{l}\text { RR: } 42 \% \\
\text { TTP: } 4.8 \text { months } \\
\text { OS: } 22 \text { months }\end{array}$ \\
\hline$\|$ & Ixabepilone 40 mg/m² every 3 weeks [45] & 2nd line after taxane & 49 & $\begin{array}{l}\text { RR: } 12 \% \\
\text { TTP: } 2.2 \text { months } \\
\text { OS: } 7.9 \text { months }\end{array}$ \\
\hline$\|$ & Ixabepilone 40 mg/m² every 3 weeks [44] & $\begin{array}{l}\text { 3rd/4th line; anthracycline, } \\
\text { taxane, and capecitabine }\end{array}$ & 126 & $\begin{array}{l}\text { RR: } 12 \% \\
\text { PFS: } 3.1 \text { months }\end{array}$ \\
\hline$\|$ & Ixabepilone $6 \mathrm{mg} / \mathrm{m}^{2}$ per day days $1-5$ every 3 weeks [43] & 1st/2nd line & 23 & $\begin{array}{l}\text { RR: } 57 \% \\
\text { TTP: } 5.5 \text { months }\end{array}$ \\
\hline$\|$ & Eribulin $1.4 \mathrm{mg} / \mathrm{m}^{2}$ every week $\times 2$ weeks every 3 weeks [47] & Median 4 prior & 332 & $\begin{array}{l}\text { RR: } 9 \%-14 \% \\
\text { PFS: } 2.6 \text { months } \\
\text { OS: } 9 \text { months }\end{array}$ \\
\hline III & $\begin{array}{l}\text { Eribulin } 1.4 \mathrm{mg} / \mathrm{m}^{2} \text { every week } \times 2 \text { weeks every } 3 \text { weeks vs. } \\
\text { physician choice [48] }\end{array}$ & Median 4 prior & 762 & $\begin{array}{l}\text { PFS: } 3.7 \text { vs. } 2.2 \text { months } \\
\text { OS: } 13.1 \text { vs. } 10.6 \text { months }^{\mathrm{a}}\end{array}$ \\
\hline$\|$ & $\begin{array}{l}\text { Capecitabine } 1,255 \mathrm{mg} / \mathrm{m}^{2} \text { twice a day } \times 14 \text { days every } \\
3 \text { weeks [49] }\end{array}$ & Unlimited & 75 & $\begin{array}{l}\text { RR: } 26 \% \\
\text { OS: } 12.2 \text { months }\end{array}$ \\
\hline$\|$ & $\begin{array}{l}\text { Capecitabine } 1,250 \mathrm{mg} / \mathrm{m}^{2} \text { twice a day } \times 14 \text { days every } 3 \text { weeks vs. } \\
\text { capecitabine } 1,000 \mathrm{mg} / \mathrm{m}^{2} \text { twice a day } \times 14 \text { days every } 3 \text { weeks [51] }\end{array}$ & 1st/2nd line & 73 & $\begin{array}{l}\text { RR: } 37 \% \text { vs. } 35 \% \\
\text { TTP: } 4 \text { vs. } 4 \text { months }\end{array}$ \\
\hline
\end{tabular}




\begin{tabular}{|c|c|c|c|c|}
\hline Phase & Drug/Regimen & Line of therapy & Number & Findings \\
\hline$\|$ & $\begin{array}{l}\text { Capecitabine } 1,255 \mathrm{mg} / \mathrm{m}^{2} \text { twice a day } \times 14 \text { days every } 3 \text { weeks } \\
\text { vs. cyclophosphamide } 600 \mathrm{mg} / \mathrm{m}^{2}+\text { methotrexate } 40 \mathrm{mg} / \mathrm{m}^{2}+ \\
5 \text {-fluorouracil } 600 \mathrm{mg} / \mathrm{m}^{2} \text { every } 3 \text { weeks [84] }\end{array}$ & 1st line & 95 & $\begin{array}{l}\text { RR: } 30 \% \text { vs. } 16 \% \\
\text { TTP: } 4.2 \text { vs. } 3 \text { months } \\
\text { OS: } 19.6 \text { vs. } 17.2 \text { months }\end{array}$ \\
\hline III & $\begin{array}{l}\text { Capecitabine } 1,250 \mathrm{mg} / \mathrm{m}^{2} \text { twice a day } \times 14 \text { days every } 3 \text { weeks vs. } \\
\text { ixabepilone } 40 \mathrm{mg} / \mathrm{m}^{2} \text { every } 3 \text { weeks }+ \text { capecitabine } 1,000 \mathrm{mg} / \mathrm{m}^{2} \\
\text { twice a day } \times 14 \text { days every } 3 \text { weeks [56] }\end{array}$ & 3rd line & 1,221 & $\begin{array}{l}\text { RR: } 29 \% \text { vs. } 43 \%^{\mathrm{a}} \\
\text { PFS: } 4.2 \text { vs. } 6.2 \text { months }^{\mathrm{a}} \\
\text { OS: } 15.6 \text { vs. } 16.4 \text { months }\end{array}$ \\
\hline$\|$ & $\begin{array}{l}\text { Gemcitabine } 1,200 \mathrm{mg} / \mathrm{m}^{2} \text { every week } \times 3 \text { weeks every } 4 \text { weeks } \\
\text { [52] }\end{array}$ & 1st line & 39 & $\begin{array}{l}\text { RR: } 37 \% \\
\text { TTP: } 5.1 \text { months } \\
\text { OS: } 21.1 \text { months }\end{array}$ \\
\hline$\|$ & $\begin{array}{l}\text { Gemcitabine } 800-850 \mathrm{mg} / \mathrm{m}^{2} \text { every week } \times 3 \text { weeks every } 4 \text { weeks } \\
\text { [85] }\end{array}$ & 1st-4th line & 81 & $\begin{array}{l}\text { RR: } 20 \%-25 \% \\
\text { OS: } 11-11.5 \text { months }\end{array}$ \\
\hline
\end{tabular}

aStatistically significant. CBR, clinical benefit rate; d, docetaxel arm; OS, overall survival; PFS, progression-free survival; RR, response rate; TTP, time to progression.

some fatigue, fluid retention, and excess lacrimation but less myelosuppression and neuropathy [37]. Nab-paclitaxel appears to be more effective and convenient than paclitaxel and docetaxel and affords the benefit of taxane therapy without the steroid premedication $[38,39]$.

\section{Non-taxane microtubule inhibitor single-agent cytotoxic therapy: vinorelbine, ixabepilone, and eribulin}

Other microtubule inhibitors efficacious in the treatment of metastatic disease in those exposed/resistant to anthracyclines and taxanes include vinorelbine, ixabepilone, and eribulin. Nearly a quarter of patients who progressed through anthracyclines and taxanes treated with weekly vinorelbine (dose modified to $25 \mathrm{mg} / \mathrm{m}^{2}$ because of hematologic toxicity and neurotoxicity) had an objective response [40]. Vinorelbine binds to tubulin, inhibiting tubulin polymerization, and this may explain why sensitivity to vinorelbine is retained among patients pretreated with taxanes as excess depolymerized tubulin has been noted in vitro [9].

Ixabepilone - an epothilone B analog that increases polymerization but that, unlike the taxanes, has the capacity to bind to multiple isomers of tubulin - has been evaluated in the setting of patients pretreated with anthracyclines, taxanes, and capecitabine as well as in first-line metastatic treatment of patients treated with adjuvant anthracyclines. In the first-line setting, women with $\mathrm{MBC}$ achieved an overall RR of $41.5 \%$ and a median survival of 22 months [41,42]. Modifications in the administration schedule of ixabepilone in a group of women who had not had prior taxane exposure did reduce neurotoxicity while maintaining RRs comparable to those of historical controls of docetaxel or paclitaxel in the first- or second-line metastatic setting [43]. Women with taxane-resistant metastatic disease or those pretreated with taxanes and capecitabine had RRs ranging from $11 \%$ to $12 \%$ and a durable response of nearly 6 months $[44,45]$. In this heavily pretreated population with prior exposure to taxane therapy, half experienced reversible sensory neuropathy.

Eribulin is the latest non-taxane microtubule inhibitor with a mechanism distinct from that of taxanes, epothilones, and vinca alkaloids in that it affects centromere dynamics and sequesters tubulin into nonfunctional aggregates and, like vinorelbine, decreases polymerization of microtubules [46]. Phase II studies have shown efficacy in populations pretreated with anthracyclines and taxane as well as capecitabine. Despite a median of four prior regimens, women still achieved RRs ranging from $9 \%$ to $14 \%$ and a PFS of approximately 2.6 months $[46,47]$. A phase III trial randomly assigning heavily pretreated patients to eribulin showed an improvement in OS of 13.1 months compared with 10.6 months in women treated according to physician's choice. Neutropenia (52\%), fatigue (54\%), and neuropathy (35\%) were common toxicities [48].

\section{Antimetabolite single-agent cytotoxic therapy: capecitabine and gemcitabine}

Antimetabolite therapy should be considered in women with prior exposure to anthracycline and taxane therapy. Capecitabine is an orally administered precursor of 5-deoxy-5-fluorouridine monotherapy that is preferentially converted in tumor tissue through exploitation of high intratumoral concentrations of thymidine phosphorylase to 5-fluorouracil [9]. A group of women who had received over three prior cytotoxic regimens, including prior anthracycline and taxane therapy, achieved an objective RR of $26 \%$ and a median survival of 12.2 months with capecitabine monotherapy, even though nearly half required dose reduction. Retrospective analysis suggested that dose reduction for palmar-plantar erythrodysesthesia, diarrhea, and nausea did not affect efficacy [49]. Capecitabine monotherapy was also tested in the firstline setting against cyclophosphamide/methotrexate/fluorouracil with comparable RRs, although palmar-plantar 
erythrodysesthesia induced by capecitabine required treatment interruptions and dose reductions in a third of patients [50]. Capecitabine at a lower dose of $1,000 \mathrm{mg} /$ $\mathrm{m}^{2}$ daily for 14 days out of a 21 -day cycle was compared with previously tested regimens of $1,250 \mathrm{mg} / \mathrm{m}^{2}$ to assess safety in women at least 65 years old, half of whom had received prior systemic treatments. The lower dose afforded similar rates of tumor response with better tolerability in the lower-dose group [51].

Gemcitabine has also been evaluated as single-agent therapy in multiple trials in both the first-line and refractory/resistant setting in doses ranging from 800 to $1,200 \mathrm{mg} / \mathrm{m}^{2}$ weekly for 3 weeks on a 28 -day cycle with RRs as varied as $14.5 \%$ to $37 \%$ and OS of 21 months in the first-line setting to RRs of $20 \%$ to $37.1 \%$ and OS of 11 months in a pretreated setting $[52,53]$.

\section{Combination cytotoxic therapy}

Combination therapies generally increase RR and TTP but with a concomitant increase in toxicity. Moreover, a critical shortcoming of studies in this area is the use of study designs in which the combination is compared with one or the other of the agents alone. The lack of comparison between sequential use of both agents and the combination biases these studies in favor of the combination. Many cytotoxic combinations have been assessed in the metastatic setting; however, only a few have shown synergy in phase III studies to prolong OS over single-agent cytotoxics with manageable toxicities, and these regimens will be reviewed here.

The low myelotoxicity associated with capecitabine made it an attractive agent to consider in combination with other cytotoxics, and preclinical work showing tumor overexpression of thymidine phosphorylase by taxanes suggested that this was an opportunity for synergy. Patients pretreated with anthracycline (prior paclitaxel was permitted) were randomly assigned to capecitabine/docetaxel or docetaxel monotherapy, and the combination resulted in an increased RR, TTP, and OS, but the improvement in efficacy was at the cost of more grade 3 adverse events ( $71 \%$ versus $49 \%)$ in the combination arm. The $1,250 \mathrm{mg} / \mathrm{m}^{2}$ twice daily dose of capecitabine may have been too high to use in combination with docetaxel given evidence that $1,000 \mathrm{mg} / \mathrm{m}^{2}$ twice daily of capecitabine monotherapy was equivalent to higher doses in women at least 65 years old. Treatment interruption was required in $34 \%$ of capecitabine cycles and $27 \%$ of docetaxel cycles compared with $20 \%$ in the single-agent arm [50]. This trial did not answer the question of whether sequential administration would have had equivalent benefit with less toxicity.

Another study compared the combination of gemcitabine plus paclitaxel to gemcitabine alone in the first-line treatment of metastatic disease. Median survival was 18.6 versus 15.8 months $(P=0.0489)$ with a longer TTP $(6.14$ versus 3.98 months; $P=0.0002)$ and a higher RR $(41.4 \%$ versus $26.2 \% ; P=0.0002)$. However, the $22 \%$ improvement in OS and $43 \%$ improvement in TTP were at the expense of more neutropenia, fatigue, and neuropathy. Again, the trial did not answer the question of whether sequential single-agent therapy would have yielded equivalent results [54]. The study design also precluded comparison with a weekly paclitaxel schedule which appears preferential to a three-weekly schedule in the advanced setting $[34,54,55]$.

A third combination regimen that has shown synergy is ixabepilone plus capecitabine in women previously treated with, but not necessarily resistant to, anthracycline and taxane therapy [56]. Although the combination arm had better PFS, there was no significant difference in OS between the two arms. Notably, there was an imbalance between the two groups in performance status. After adjustment for performance status, OS was also improved in the combination arm. Nearly a quarter of those in the ixabepilone plus capecitabine arm experienced reversible grade 3 or 4 neuropathy.

Given the proposed deficiency of DNA repair mechanisms in triple-negative and basal-like tumors, platinumbased chemotherapy combinations have been presented as a strategy to treat these subtypes of MBC. Although phase II studies of carboplatin- or cisplatin-based combination regimens have demonstrated overall RRs ranging from $29 \%$ to $41 \%$ in triple-negative $\mathrm{MBC}$, these responses are often at the expense of significant hematologic and non-hematologic side effects, including peripheral neuropathy, nephrotoxicity, and nausea [5759]. In light of the high rates of grade $3 / 4$ toxicities for a palliative regimen and absence of prospective phase III data showing improvement in PFS and OS, use of combination platinum-based therapy in triple-negative $\mathrm{MBC}$ warrants further study [60].

In summary, women whose $\mathrm{MBC}$ requires cytotoxic therapy have multiple alternatives. Monotherapy is preferable to minimize side effects given the paucity of data comparing combination regimens to sequential use of single agents. Presuming adequate performance status, women with prior exposure to anthracyclines only should receive paclitaxel, albumin-bound paclitaxel, or docetaxel as first-line treatment for their triple-negative or endocrine-refractory metastatic disease. Women who have progressed through taxane therapy can be treated with alternative microtubule inhibitors such as vinorelbine or eribulin if they do not have prohibitive residual neuropathy. A reasonable alternative is to treat these women with either capecitabine or gemcitabine. Combination cytotoxic regimens should be reserved for women who have good performance status and whose organ function is threatened by rapidly progressive disease. 


\section{Bevacizumab}

The addition of bevacizumab to cytotoxic therapy for the first-line treatment of Her2-negative $\mathrm{MBC}$ has recently undergone considerable scrutiny. In 2008, the FDA granted accelerated approval for its use in combination with chemotherapy based on a 5.5-month increase in PFS achieved in E2100, which compared paclitaxel plus bevacizumab with paclitaxel alone [61]. Subsequent trials, including AVADO (Avastin and Docetaxel ), RIBBON (Regimens in Bevacizumab for Breast Oncology ), and TRIO-10 (Translational Research In Oncology), which evaluated the addition of bevacizumab to taxanes, anthracyclines, and capecitabine, showed notably smaller, albeit statistically significant, improvements in PFS [6265]. As with E2100, these trials showed no improvement in OS, and, in some instances, OS appeared to favor the chemotherapy-alone arms. Although some women appear to benefit from bevacizumab, there remains no clear marker to predict activity and bevacizumabcontaining arms did have more adverse events that were serious. As a result of these analyses, the National Institute for Health and Clinical Excellence in the UK concluded in February 2011 that the addition of bevacizumab was not a cost-effective use of resources and the FDA decided in June 2011 to revoke the indication for the use of bevacizumab in MBC [66,67]. To date, compendium guidelines put forth by the National Comprehensive Cancer Network still support consideration of weekly paclitaxel and bevacizumab, and the European Medicines Agency endorses the addition of bevacizumab to paclitaxel or capecitabine as a viable option in $\mathrm{MBC}$.

\section{Future directions: molecular subtypes and targeted therapy}

While ER, PR, and Her2 status primarily inform the selection of therapy for $\mathrm{MBC}$, recent advances in genomic analysis have provided insight into metastatic behavior of breast cancers within specific biologic subtypes. In addition to the conventional prognostic factors of size and lymph node involvement, analysis of archival specimens in women by breast cancer subtypes such as luminal A, luminal B, luminal/Her2-enriched, non-luminal/Her2-enriched, basal-like, and triplenegative tumors - appears to show different patterns of relapse and response to treatment [29]. ER ${ }^{-}$tumors (characteristic of non-luminal/Her2-enriched, basal-like, or triple-negative subtypes) are associated with early relapse and a higher proportion of metastatic disease involving the central nervous system, whereas $\mathrm{ER}^{+}$ tumors (characteristic of luminal A, luminal B, or luminal/Her2-enriched subtypes) carry a risk of late relapse with a predilection for bone. Her2-enriched tumors (characteristic of luminal/Her2 or non-luminal/
Her2-enriched subtypes) demonstrate a high relapse rate in the brain, liver, and lung. Triple-negative basal-like tumors demonstrate a high and early relapse rate, with a greater incidence of brain, lung, and nodal metastases; triple-negative non-basal like subtypes also demonstrate a higher rate of visceral involvement that includes a greater proportion of liver metastases [29]. Although molecular subtype analysis is not yet a standard component of pathologic evaluation, knowledge of these subtypes in the future may add to the evaluation of women with $\mathrm{MBC}$, affording both prognostic and predictive tools.

Molecular profiling will ideally enable analysis within and across subtypes to isolate therapeutic targets as different tumor subtypes appear to share some mutational hotspots. New agents targeting critical pathways in metastatic disease are currently in late-stage development (Table 3), and combinations of these agents and existing therapies will undoubtedly be necessary to better control systemic disease.

The development of endocrine-refractory, $\mathrm{ER}^{+}$metastatic disease appears to involve cell signaling pathways, including insulin-like growth factor receptor-I (IGFR-I) and mTOR. Although early results from IGFR-I inhibitors in overcoming resistance to AIs have been disappointing, the results from BOLERO-2 demonstrating the potential for use of mTOR inhibition to overcome AI resistance appear to be a promising alternative to cytotoxic therapy in these patients.

Proteins involved in DNA repair, such as poly (ADPribose) polymerase (PARP), are a therapeutic target in both BRCA mutation carriers and non-BRCA mutant triple-negative tumors. In basal-like subtype and sporadic triple-negative patients, intrinsic hypermethylation of the BRCA gene in combination with PARP inhibition may afford the synthetic lethality necessary to make these tumors more susceptible to cell death from chemotherapy [53]. Phase II data initially demonstrated that patients with triple-negative MBC had an improvement in CBR and OS when treated with PARP inhibitor iniparib when combined with carboplatin and gemcitabine; however, results of the phase III trial presented at the 2011 ASCO meeting did not result in a significant increase in OS and PFS $[68,69]$. Although phase I and II studies testing olaparib showed response in BRCA1/2 mutation carriers with $\mathrm{MBC}$, current trials have shifted the clinical focus of this drug toward ovarian carcinoma [70]. Velaparib, for which phase II results of a combination regimen with temozolomide were presented at the 2010 ASCO meeting, also showed lower-than-expected RRs [71]. Unfortunately, the initial promise of PARP inhibitors in triple-negative patients with $\mathrm{MBC}$ has yet to be realized.

Other potential targets that appear specific to basallike and triple-negative tumors include hedgehog ligands and tyrosine phosphatases. Overexpression of hedgehog 
Table 3. Selected compounds currently under investigation for use in metastatic breast cancer

\begin{tabular}{|c|c|c|c|}
\hline Target & Agent (Company) & Mechanism [9] & Status [86] \\
\hline $\begin{array}{l}\text { Poly ADP-ribose } \\
\text { polymerase (PARP) }\end{array}$ & $\begin{array}{l}\text { Olaparib (AstraZeneca, London, UK) and } \\
\text { Iniparib (Sanofi, Paris, France) }\end{array}$ & $\begin{array}{l}\text { Inhibits PARP-mediated repair of single-stranded DNA } \\
\text { breaks potentially enhancing cytotoxicity of DNA- } \\
\text { damaging agents }\end{array}$ & Phase II and III (Iniparib) \\
\hline
\end{tabular}

Vascular endothelial Ramucirumab/IM-111B (Eli Lilly and growth factor Company, Indianapolis, IN, USA) receptor-2 (VEGFR-2)

FK-binding protein-12 (FKBP-12)
Everolimus (Novartis, East Hanover, NJ, USA) activation of mammalian target of rapamycin (mTOR), a regulatory kinase, resulting in inhibition of T lymphocyte activation and proliferation associated with antigen and cytokine stimulation and inhibition of antibody production. Inhibiting the mTOR pathway could overcome endocrine resistance mediated by ligandindependent receptor activation ligands, thought to mediate tumor-stromal interactions, in basal-like tumors is associated with poor prognosis, and blockade of this ligand may afford another therapeutic target. Tyrosine phosphatases, such as PTPN12 (tyrosine-protein phosphatase non-receptor type 12), normally inhibit tyrosine kinases such as epidermal growth factor receptor (EGFR) and Her2 and may act as tumor suppressors. Their expression is frequently lost or inactivated in triple-negative tumors, and, as such, these subtypes may be more sensitive to inhibitors of tyrosine kinase inhibitors. However, as yet, phase III trials adding agents like sunitinib to standard cytotoxics like docetaxel have not demonstrated improved outcomes compared with cytotoxic monotherapy [72].

Preclinical work examining the role of proto-oncogene c-Met, also known as hepatocyte growth factor receptor, in the pathogenesis of basaloid tumors and trastuzumabresistant, Her2-positive tumors points to another potential opportunity for targeted therapy $[9,19,73]$. Oral small-molecule inhibitors of c-Met are currently in phase I trials both as monotherapy and in combination with gemcitabine and sorafenib [74-76].

\section{Conclusions}

Despite the development of numerous new agents over the past two decades and the rare durable remission, $\mathrm{MBC}$ remains an incurable disease. While the treatment of women with $\mathrm{MBC}$ will become even more complex as novel therapies emerge alongside of clinical decisionmaking tools that allow personalization of therapies according to molecular and genomic subtype, one basic principle ultimately will remain unchanged: do no harm. The current goal of care in metastatic disease is to palliate. Any therapeutic approach that seeks to harness the potential of a given drug to improve upon existing RRs and survival must be balanced against toxicities.

\section{Abbreviations}

$\mathrm{Al}$, aromatase inhibitor; ASCO, American Society of Clinical Oncology; BOLERO-2, Breast Cancer Trials of Oral Everolimus-2; CBR, clinical benefit rate; ER, estrogen receptor; FDA, US Food and Drug Administration; $\mathrm{GnRH}$, gonadotropin-releasing hormone; IGFR-I, insulin-like growth factor receptor-l; MA, megestrol acetate; MBC, metastatic breast cancer; mTOR, mammalian target of rapamycin; OS, overall survival; PARP, poly (ADP-ribose) polymerase; PFS, progression-free survival; PLD, pegylated liposomal doxorubicin; PR, progesterone receptor; $\mathrm{RR}$, response rate; TTP, time to progression.

\section{Competing interests}

The authors declare that they have no competing interests.

\section{Author details}

${ }^{1}$ Rena Rowan Breast Center, Abramson Cancer Center, University of Pennsylvania, Perelman Center for Advanced Medicine, West Pavilion, 3rd Floor, 3400 Civic Center Boulevard, Philadelphia, PA 19104, USA. ²Department of Medicine, Division of Hematology/Oncology, University of Pennsylvania, 3400 Spruce Street, Philadelphia, PA 19104, USA. ${ }^{3}$ Center for Clinical Epidemiology and Biostatistics, Department of Biostatistics and Epidemiology, 8th Floor, Blockley Hall, 423 Guardian Drive, Philadelphia, PA 19104-6021, USA.

Published: 19 March 2012

\section{References}

1. Howlader N, Noone AM, Krapcho M, Neyman N, Aminou R, Waldron W, Altekruse SF, Kosary CL, Ruhl J, Tatalovich Z, Cho H, Mariotto A, Eisner MP, Lewis DR, Chen HS, Feuer EJ, Cronin KA, Edwards BK (eds). SEER Cancer Statistics Review, 1975-2008. Bethesda, MD: National Cancer Institute [http:// seer.cancer.gov/csr/1975_2008/].

2. Khatcheressian JL, Wolff AC, Smith TJ, Grunfeld E, Muss HB, Vogel VG, Halberg F, Somerfield MR, Davidson NE; American Society of Clinical Oncology: American Society of Clinical Oncology 2006 update of the breast cancer follow-up and management guideline in the adjuvant Setting. J Clin Oncol 2006, 2:5091-5097.

3. NCCN Guidelines Breast Cancer Version 2.2011 [http://www.nccn.org/ professionals/physician_gls/pdf/breast.pdf].

4. Harris L, Fritsche H, Mennel R, Norton L, Ravdin P, Taube S, Somerfield MR, Hayes DF, Bast RC Jr.; American Society of Clinical Oncology: American Society of Clinical Oncology 2007 update of recommendations for the use of tumor markers in breast cancer. J Clin Oncol 2007, 25:5287-5312.

5. Pusztai L, Viale G, Kelly CM, Hudis CA: Estrogen and HER-2 receptor discordance between primary breast cancer and metastasis. Oncologist 2010, 15:1164-1168.

6. Mi Z, Holmes FA, Hellerstedt B, Pippen J, Collea R, Backner A, Bush JE, Gallion $\mathrm{HH}$, Wells A, O'Shaughnessy JA: Feasibility assessment of a chemoresponse assay to predict pathologic response in neoadjuvant chemotherapy for 
breast cancer patients. Anticancer Res 2008, 28:1733-1740

7. Baselga J, Campone M, Piccart M, Burris H, III, Rugo HS, Sahmoud T, Noguchi S, Gnant M, Pritchard KI, Lebrun F, Beck JT, Ito Y, Yardley D, Deleu I, Perez A, M Bachelot T, Vittori L, Xu Z, Mukhopadhyay P, Lebwohl D, Hortobagyi GN: Everolimus in postmenopausal hormone-receptor-positive advanced breast cancer. N Engl J Med 2011 December 7, Epub ahead of print.

8. Early Breast Cancer Trialists' Collaborative Group (EBCTCG): Effects of chemotherapy and hormonal therapy for early breast cancer on recurrence and 15-year survival: an overview of the randomised trials. Lancet 2005, 365:1687-1717.

9. $\mathrm{NCI}$ Drug Dictionary [http://www.cancer.gov/drugdictionary].

10. Ingle JN, Krook JE, Green SJ, Kubista TP, Everson LK, Ahmann DL, Chang MN, Bisel HF, Windschitl HE, Twito DI, Pfiefle DM: Randomized trial of bilateral oopherectomy versus tamoxifen in premenopausal women with metastatic breast cancer. J Clin Oncol 1986, 4:178-185.

11. Boccardo F, Rubagotti A, Perrotta A, Amoroso D, Balestrero M, De Matteis A, Zola P, Sismondi P, Francini G, Petrioli R, Sassi M, Pacini P, Galligioni E: Ovarian ablation versus goserelin with or without tamoxifen in preperimenopausal patients with advanced breast cancer: results of a multicentric Italian study. Ann Oncol 1994, 5:337-342.

12. Klijn JG, Blamey RW, Boccardo F, Tominaga T, Duchateau L, Sylvester R; Combined Hormone Agents Trialists' Group and the European Organization for Research and Treatment of Cancer: Combined tamoxifen and luteinizing hormone-releasing hormone (LHRH) agonist versus LHRH agonist alone in premenopausal advanced breast cancer: a meta-analysis of four randomized trials. J Clin Oncol 2001, 19:343-353.

13. Hughes LL, Gray RJ, Solin LJ, Robert NJ, Martino S, Tripathy D, Ingle JN, Wood WC; Eastern Cooperative Oncology Group; Southwest Oncology Group; Cancer and Leukemia Group B; North Central Cancer Treatment Group: Efficacy of radiotherapy for ovarian ablation: results of a breast intergroup study. Cancer 2004, 101:969-972.

14. Sverrisdottir A, Johansson H, Johansson U, Bergh J, Rotstein S, Rutqvist LE, Fornander T: Interaction between goserelin and tamoxifen in a controlled clinical trial of adjuvant endocrine therapy in premenopausal breast cancer. San Antonio Breast Cancer Symposium 2010, S1-5.

15. Di Leo A, Jerusalem G, Petruzelka L, Torres R, Bondarenko IN, Khasanov R, Verhoeven D, Pedrini JL, Smirnova I, Lichinitser MR, Pendergrass K, Garnett S, Lindemann JP, Sapunar F, Martin M: Results of the CONFIRM phase III trial comparing fulvestrant $250 \mathrm{mg}$ with fulvestrant $500 \mathrm{mg}$ in postmenopausal women with estrogen receptor-positive advanced breast cancer. J Clin Oncol 2010, 28:4594-4600

16. Ingle JN, Suman VJ, Rowland KM, Mirchandani D, Bernath AM, Camoriano JK, Fishkin PA, Nikcevich DA, Perez EA; North Central Cancer Treatment Group Trial N0032: Fulvestrant in women with advanced breast cancer after progression on prior aromatase inhibitor therapy: North Central Cancer Treatment Group Trial N0032. J Clin Oncol 2006, 24:1052-1056.

17. Robertson JF, Llombart-Cussac A, Rolski J, Feltl D, Dewar J, Macpherson E, Lindemann J, Ellis MJ: Activity of fulvestrant $500 \mathrm{mg}$ versus anastrozole $1 \mathrm{mg}$ as first-line treatment for advanced breast cancer: results from the FIRST study. J Clin Oncol 2009, 27:4530-4535.

18. Goss PE, Winer EP, Tannock IF, Schwartz LH: Randomized phase III trial comparing the new potent and selective third-generation aromatase inhibitor vorozole with megestrol acetate in postmenopausal advanced breast cancer patients. J Clin Oncol 1999, 17:52-63.

19. Shattuck DL, Miller JK, Carraway KL 3rd, Sweeney C: Met receptor contributes to trastuzumab resistance of Her2-overexpressing breast cancer cells. Cancer Res 2008, 68:1471-1477.

20. Bonneterre J, Buzdar A, Nabholtz JM, Robertson JF, Thürlimann B, von Euler M, Sahmoud T, Webster A, Steinberg M; Arimidex Writing Committee; Investigators Committee Members: Anastrozole is superior to tamoxifen as first-line therapy in hormone receptor positive advanced breast carcinoma. Cancer 2001, 92:2247-2258.

21. Mouridsen H, Sun Y, Gershanovich M, Perez-Carrion R, Becquart D, ChaudriRoss HA, Lang R: Superiority of letrozole to tamoxifen in the first-line treatment of advanced breast cancer: evidence from metastatic subgroups and a test of functional ability. Oncologist 2004, 9:489-496.

22. Paridaens RJ, Dirix LY, Beex LV, Nooij M, Cameron DA, Cufer T, Piccart MJ, Bogaerts J, Therasse P: Phase III study comparing exemestane with tamoxifen as first-line hormonal treatment of metastatic breast cancer in postmenopausal women: the European Organisation for Research and Treatment of Cancer Breast Cancer Cooperative Group. J Clin Oncol 2008,
26:4883-4890

23. Kaufmann M, Bajetta E, Dirix LY, Fein LE, Jones SE, Zilembo N, Dugardyn JL, Nasurdi C, Mennel RG, Cervek J, Fowst C, Polli A, di Salle E, Arkhipov A, Piscitelli G, Miller LL, Massimini G: Exemestane improves survival in metastatic breast cancer: results of a phase III randomized study. Clin Breast Cancer 2000, 1 (suppl 1):S15-18.

24. Campos SM, Guastalla JP, Subar M, Abreu P, Winer EP, Cameron DA: A comparative study of exemestane versus anastrozole in patients with postmenopausal breast cancer with visceral metastases. Clin Breast Cancer 2009, 9:39-44.

25. Brufman G, Isacson R, Haim N, Gez E, Sulkes A: Megestrol acetate in advanced breast carcinoma after failure to tamoxifen and/or aminoglutethimide. Oncology 1994, 51:258-261.

26. Ellis MJ, Gao F, Dehdashti F, Jeffe DB, Marcom PK, Carey LA, Dickler MN Silverman P, Fleming GF, Kommareddy A, Jamalabadi-Majidi S, Crowder R, Siegel BA: Lower-dose vs. high-dose oral estradiol therapy of hormone receptor-positive, aromatase inhibitor-resistant advanced breast cancer: a phase 2 randomized study. JAMA 2009, 302:774-780.

27. Kaufman PA, Ferrero JM, Bourgeois $H$, Kennecke H, De Boer R, Jacot W, McGreivy J, Suzuki S, Loh E, Robertson J: A randomized, double-blind, placebo-controlled, phase 2 study of AMG 479 with exemestane (E) or fulvestrant $(F)$ in postmenopausal women with hormone-receptor positive $(\mathrm{HR}+$ ) metastatic $(\mathrm{M})$ or locally advanced (LA) breast cancer (BC) [abstract]. San Antonio Breast Cancer Symposium 2010, S1-4.

28. Bachelot T, Bourgier C, Cropet C, Guastalla J-P, Ferrero J-M, Leger-Falandry C, Soulie P, Eymard J-C, Debled M, Spaeth D, Legouffe E, Delozier T, El Kouri C, Chidiac J: TAMRAD: a GINECO randomized phase II trial of everolimus in combination with tamoxifen versus tamoxifen alone in patients (pts) with hormone-receptor positive, HER2 negative metastatic breast cancer (MBC) with prior exposure to aromatase inhibitors (Al) [abstract]. San Antonio Breast Cancer Symposium 2010, S1-6.

29. Kennecke H, Yerushalmi R, Woods R, Cheang MC, Voduc D, Speers CH, Nielsen TO, Gelmon K: Metastatic behavior of breast cancer subtypes. J Clin Oncol 2010, 28:3271-3277.

30. Chan S, Friedrichs K, Noel D, Pintér T, Van Belle S, Vorobiof D, Duarte R, Gil Gil M, Bodrogi I, Murray E, Yelle L, von Minckwitz G, Korec S, Simmonds P, Buzzi F, González Mancha R,Richardson G, Walpole E, Ronzoni M, Murawsky M, Alakl M, Riva A, Crown J; 303 Study Group: Prospective randomized trial of docetaxel versus doxorubicin in patients with metastatic breast cancer. J Clin Oncol 1999, 17:2341-2454.

31. Bastholt L, Dalmark M, Gjedde SB, Pfeiffer P, Pedersen D, Sandberg E, Kjaer M, Mouridsen HT, Rose C, Nielsen OS, Jakobsen P, Bentzen SM: Dose-response relationship of epirubicin in the treatment of postmenopausal patients with metastatic breast cancer: a randomized study of epirubicin at four different dose levels performed by the Danish Breast Cancer Cooperative Group. J Clin Oncol 1996, 14:1146-1166.

32. O'Brien ME, Wigler N, Inbar M, Rosso R, Grischke E, Santoro A, Catane R, Kieback DG, Tomczak P, Ackland SP, Orlandi F, Mellars L, Alland L, Tendler C; CAELYX Breast Cancer Study Group: Reduced cardiotoxicity and comparable efficacy in a phase III trial of pegylated liposomal doxorubicin $\mathrm{HCl}$ (CAELYX/Doxil) versus conventional doxorubicin for first-line treatment of metastatic breast cancer. Ann Oncol 2004, 15:440-449.

33. Jones SE, Erban J, Overmoyer B, Budd GT, Hutchins L, Lower E, Laufman L, Sundaram S, Urba WJ, Pritchard KI, Mennel R, Richards D, Olsen S, Meyers ML, Ravdin PM: Randomized phase III study of docetaxel compared with paclitaxel in metastatic breast cancer. J Clin Oncol 2005, 23:5542-5551.

34. Seidman AD, Berry D, Cirrincione C, Harris L, Muss H, Marcom PK, Gipson G, Burstein $H$, Lake D, Shapiro CL, Ungaro P, Norton L, Winer E, Hudis C: Randomized phase III trial of weekly compared with every-3-weeks paclitaxel for metastatic breast cancer, with trastuzumab for all HER-2 overexpressors and random assignment to trastuzumab or not in HER-2 nonoverexpressors: final results of Cancer and Leukemia Group B protocol 9840. J Clin Oncol 2008, 26:1642-1649.

35. Perez EA, Vogel CL, Irwin DH, Kirshner JJ, Patel R: Multicenter phase II trial of weekly paclitaxel in women with metastatic breast cancer. $J$ Clin Oncol 2001, 19:4216-4223.

36. Burris HA 3rd: Single-agent docetaxel (Taxotere) in randomized phase III trials. Semin Oncol 1999, 26 (3 suppl 9):1-6.

37. Burstein HJ, Manola J, Younger J, Parker LM, Bunnell CA, Scheib R, Matulonis UA, Garber JE, Clarke KD, Shulman LN, Winer EP: Docetaxel administered on a weekly basis for metastatic breast cancer. J Clin Oncol 2000, 18:1212-1219. 
38. Gradishar WJ, Tjulandin S, Davidson N, Shaw H, Desai N, Bhar P, Hawkins M, O'Shaughnessy J: Phase III trial of nanoparticle albumin-bound paclitaxel compared with polyethylated castor oil-based paclitaxel in women with breast cancer. J Clin Oncol 2005, 23:7794-7803.

39. Gradishar WJ, Krasnojon D, Cheporov S, Makhson AN, Manikhas GM, Clawson A, Bhar P: Significantly longer progression-free survival with nab-paclitaxel compared with docetaxel as first-line therapy for metastatic breast cancer. J Clin Oncol 2009, 27:3611-3619.

40. Zelek L, Barthier S, Riofrio M, Fizazi K, Rixe O, Delord JP, Le Cesne A, Spielmann $M$ : Weekly vinorelbine is an effective palliative regimen after failure with anthracyclines and taxanes in metastatic breast carcinoma. Cancer 2001, 92:2267-2272.

41. Roché H, Yelle L, Cognetti F, Mauriac L, Bunnell C, Sparano J, Kerbrat P, Delord JP, Vahdat L, Peck R, Lebwohl D, Ezzeddine R, Curé H: Phase II clinical trial of ixabepilone (BMS-247550), an epothilone B analog, as first-line therapy in patients with metastatic breast cancer previously treated with anthracycline chemotherapy. J Clin Oncol 2007, 25:3415-3420.

42. Rivera $\mathrm{E}, \mathrm{Gomez} \mathrm{H}$ : Chemotherapy resistance in metastatic breast cancer: the evolving role of ixabepilone. Breast Cancer Res 2010, 12 (suppl 2):1-12.

43. Denduluri N, Low JA, Lee JJ, Berman AW, Walshe JM, Vatas U, Chow CK, Steinberg SM, Yang SX, Swain SM: Phase II trial of ixabepilone, an epothilone B analog, in patients with metastatic breast cancer previously untreated with taxanes. J Clin Oncol 2007, 25:3421-3427.

44. Perez EA, Lerzo G, Pivot X, Thomas E, Vahdat L, Bosserman L, Viens P, Cai C, Mullaney B, Peck R, Hortobagyi GN: Efficacy and safety of ixabepilone (BMS-247550) in a phase II study of patients with advanced breast cancer resistant to an anthracycline, a taxane, and capecitabine. J Clin Oncol 2007, 25:3407-3414.

45. Thomas E, Tabernero J, Fornier M, Conté P, Fumoleau P, Lluch A, Vahdat LT, Bunnell CA, Burris HA, Viens P, Baselga J, Rivera E, Guarneri V, Poulart V, Klimovsky J, Lebwohl D, Martin M: Phase II clinical trial of ixabepilone (BMS-247550), an epothilone B analog, in patients with taxane-resistant metastatic breast cancer. J Clin Oncol 2007, 25:3399-3406.

46. Cortes J, Vahdat L, Blum JL, Twelves C, Campone M, Roché H, Bachelot T, Awada A, Paridaens R, Goncalves A, Shuster DE, Wanders J, Fang F, Gurnani R, Richmond E, Cole PE, Ashworth S, Allison MA: Phase II study of the halichondrin $B$ analog eribulin mesylate in patients with locally advanced or metastatic breast cancer previously treated with an anthracycline, a taxane, and capecitabine. J Clin Oncol 2010, 28:3922-3928.

47. Vahdat LT, Pruitt B, Fabian CJ, Rivera RR, Smith DA, Tan-Chiu E, Wright J, Tan AR, Dacosta NA, Chuang E, Smith J, O'Shaughnessy J, Shuster DE, Meneses NL, Chandrawansa K, Fang F, Cole PE, Ashworth S, Blum JL: Phase II study of eribulin mesylate, a halichondrin $B$ analog, in patients with metastatic breast cancer previously treated with an anthracycline and a taxane. J Clin Oncol 2009, 27:2954-2961.

48. Cortes J, O'Shaughnessy J, Loesch D, Blum JL, Vahdat LT, Petrakova K, Chollet P, Manikas A, Diéras V, Delozier T, Vladimirov V, Cardoso F, Koh H, Bougnoux P, Dutcus CE, Seegobin S, Mir D, Meneses N, Wanders J, Twelves C; EMBRACE (Eisai Metastatic Breast Cancer Study Assessing Physician's Choice Versus E7389) investigators: Eribulin monotherapy versus treatment of physician's choice in patients with metastatic breast cancer (EMBRACE): a phase 3 open-label randomised study. Lancet 2011, 377:914-923.

49. Blum JL, Dieras V, Lo Russo PM, Horton J, Rutman O, Buzdar A, Osterwalder B: Multicenter, phase II study of capecitabine in taxane-pretreated metastatic breast cancer. Cancer 2001, 92:1759-1768.

50. O'Shaughnessy J, Miles D, Vukelja S, Moiseyenko V, Ayoub JP, Cervantes G, Fumoleau P, Jones S, Lui WY, Mauriac L, Twelves C, Van Hazel G, Verma S, Leonard R: Superior survival with capecitabine plus docetaxel combination therapy in anthracycline-pretreated patients with advanced breast cancer: phase III trial results. J Clin Oncol 2002, 20:2812-2823.

51. Bajetta E, Procopio G, Celio L, Gattinoni L, Della Torre S, Mariani L, Catena L, Ricotta R, Longarini R, Zilembo N, Buzzoni R: Safety and efficacy of two different doses of capecitabine in the treatment of advanced breast cancer in older women. J Clin Oncol 2005, 23:2155-2161.

52. Blackstein $M$, Vogel $C L$, Ambinder R, Cowan J, Iglesias J, Melemed A: Gemcitabine as first-line therapy in patients with metastatic breast cancer: a phase II trial. Oncology 2002, 62:2-8.

53. Rha SY, Moon YH, Jeung HC, Kim YT, Sohn JH, Yang WI, Suh CO, Kim GE, Roh JK, Chung HC: Gemcitabine monotherapy as salvage chemotherapy in heavily pretreated metastatic breast cancer. Breast Cancer Res Treat 2005, 90:215-221.
54. Albain KS, Nag SM, Calderillo-Ruiz G, Jordaan JP, Llombart AC, Pluzanska A, Rolski J, Melemed AS, Reyes-Vidal JM, Sekhon JS, Simms L, O'Shaughnessy J: Gemcitabine plus paclitaxel versus paclitaxel monotherapy in patients with metastatic breast cancer and prior anthracycline treatment. J Clin Oncol 2008, 26:3950-3957.

55. Mauri D, Kamposioras K, Tsali L, Bristianou M, Valachis A, Karathanasi I, Georgiou C, Polyzos NP: Overall survival benefit for weekly vs. three-weekly taxanes regimens in advanced breast cancer: a meta-analysis. Cancer Treat Rev 2009, 36:69-74

56. Sparano JA, Vrdoljak E, Rixe O, Xu B, Manikhas A, Medina C, Da Costa SC, Ro J, Rubio G, Rondinon M, Perez Manga G, Peck R, Poulart V, Conte P: Randomized phase III trial of ixabepilone plus capecitabine versus capecitabine in patients with metastatic breast cancer previously treated with an anthracycline and a taxane. J Clin Oncol 2010, 28:3256-3263.

57. Sirohi B, Arnedos M, Popat S, Ashley S, Nerurkar A, Walsh G, Johnston S, Smith IE: Platinum-based chemotherapy in triple negative breast cancer. Ann Oncol 2008, 19:1847-1852.

58. Wang Z, Hu X, Chen L, Wang J, Wang H, Wang L, Liu G, Hu Z, Wu J, Zhimin S: Efficacy of gemcitabine and cisplatin (GP) as first-line combination therapy in patients with triple-negative metastatic breast cancer: preliminary results report of a phase II trial [abstract]. J Clin Oncol 2010, 28 (suppl):e1100.

59. Chew HK, Doroshow JH, Frankel P, Margolin KA, Somlo G, Lenz HJ, Gordon M, Zhang W, Yang D, Russell C, Spicer D, Synold T, Bayer R, Hantel A, Stiff PJ, Tetef ML, Gandara DR, Albain KS: Phase II studies of gemcitabine and cisplatin in heavily and minimally pretreated metastatic breast cancer. J Clin Oncol 2009, 27:2163-2169.

60. Staudacher L, Cottu PH, Diéras V, Vincent-Salomon A, Guilhaume MN, Escalup L, Dorval T, Beuzeboc P, Mignot L, Pierga JY: Platinum-based chemotherapy in metastatic triple-negative breast cancer: the Institut Curie experience. Ann Oncol 2011, 22:848-856.

61. Miller K, Wang M, Gralow J, Dickler M, Cobleigh M, Perez EA, Shenkier T, Cella D, Davidson NE: Paclitaxel plus bevacizumab versus paclitaxel alone for metastatic breast cancer. N Engl J Med 2007, 357:2666-2676.

62. Miles DW, Chan A, Dirix LY, Cortés J, Pivot X, Tomczak P, Delozier T, Sohn JH, Provencher L, Puglisi F, Harbeck N, Steger GG, Schneeweiss A, Wardley AM, Chlistalla A, Romieu G: Phase III study of bevacizumab plus docetaxel compared with placebo plus docetaxel for the first-line treatment of human epidermal growth factor receptor 2-negative metastatic breast cancer. J Clin Oncol 2010, 28:3239-3247.

63. Miller KD, Chap LI, Holmes FA, Cobleigh MA, Marcom PK, Fehrenbacher L, Dickler M, Overmoyer BA, Reimann JD, Sing AP, Langmuir V, Rugo HS: Randomized phase III trial of capecitabine compared with bevacizumab plus capecitabine in patients with previously treated metastatic breast cancer. J Clin Oncol 2005, 23:792-798.

64. Robert NJ, Diéras V, Glaspy J, Brufsky AM, Bondarenko I, Lipatov ON, Perez EA, Yardley DA, Chan SY, Zhou X, Phan SC, O'Shaughnessy J: RIBBON-1: randomized, double-blind, placebo-controlled, phase III trial of chemotherapy with or without bevacizumab for first-line treatment of human epidermal growth factor receptor 2-negative, locally recurrent or metastatic breast cancer. J Clin Oncol 2011, 29:1252-1260.

65. Martin M, Roche H, Pinter T, Crown J, Kennedy MJ, Provencher L, Priou F, Eiermann W, Adrover E, Lang I, Ramos M, Latreille J, Jagiełło-Gruszfeld A, Pienkowski T, Alba E, Snyder R, Almel S,Rolski J, Munoz M, Moroose R, Hurvitz S, Baños A, Adewoye H, Hei YJ, Lindsay MA, Rupin M, Cabaribere D, Lemmerick Y, Mackey JR; TRIO 010 investigators: Motesanib, or open-labe bevacizumab, in combination with paclitaxel, as first-line treatment for HER2-negative locally recurrent or metastatic breast cancer: a phase 2, randomised, double-blind, placebo-controlled study. Lancet Oncol 2011, 4:369-376.

66. National Institute for Health and Clinical Excellence: [Guideline for] Bevacizumab in combination with a taxane for the first-line treatment of metastatic breast cancer [http://guidance.nice.org.uk/TA214].

67. Hearing on Proposal to Withdraw Approval for the Breast Cancer Indication for Bevacizumab (Avastin). Washington, DC: US Food and Drug Administration; 28-29 June 2011 [http://www.fda.gov/newsevents/ meetingsconferencesworkshops/ucm255874.htm]

68. O'Shaughnessy J, Schwartzberg LS, Danso MA, Rugo HS, Miller K, Yardley DA Carlson RW, Finn RS, Charpentier E, Freese M, Gupta S, Blackwood-Chirchir A, Winer EP: A randomized phase III study of iniparib (BSI-201) in combination with gemcitabine/carboplatin $(\mathrm{G} / \mathrm{C})$ in metastatic 
triple-negative breast cancer (TNBC) [abstract]. J Clin Oncol 2011, 29(Suppl):e1007.

69. O'Shaughnessy J, Osborne C, Pippen JE, Yoffe M, Patt D, Rocha C, Koo IC Sherman BM, Bradley C: Iniparib plus chemotherapy in metastatic triplenegative breast cancer. N Engl J Med 2011, 364:205-214.

70. Tutt A, Robson M, Garber JE, Domchek SM, Audeh MW, Weitzel JN, Friedlander M, Arun B, Loman N, Schmutzler RK, Wardley A, Mitchell G, Earl H, Wickens M, Carmichael J: Oral poly(ADP-ribose) polymerase inhibitor olaparib in patients with BRCA1 or BRCA2 mutations and advanced breast cancer: a proof-of-concept trial. Lancet 2010, 376:235-244.

71. Isakoff SJ, Overmover B, Tung NM, Gelman RS, Giranda VL, Bernhard KM, Habin KR, Ellisen LW, Winer EP, Goss PE: A phase II trial of the PARP inhibitor veliparib (ABT888) and temozolomide for metastatic breast cancer [abstract]. J Clin Oncol 2010, 28(Suppl):e1019.

72. Bergh J, Greil R, Voytko N, Makhson A, Cortes J, Lortholary A, Huang X, Giorgetti C, Kern KA, Lichinitser M: Sunitinib (SU) in combination with docetaxel (D) versus $D$ alone for the first-line treatment of advanced breast cancer (ABC) [abstract]. J Clin Oncol 2010, 28(Suppl):LBA1010.

73. Ponzo MG, Lesurf R, Petkiewicz S, O'Malley FP, Pinnaduwage D, Andrulis IL, Bull SB, Chughtai N, Zuo D, Souleimanova M, Germain D, Omeroglu A, Cardiff RD, Hallett M, Park M: Met induces mammary tumors with diverse histologies and is associated with poor outcome and human basal breast cancer. Proc Natl Acad Sci U S A 2009, 106:12903-12908.

74. Adjei A, Sosman J, Martell R, Dy G, Goff L, Ma W, Horn L, Fetterly G, Michael A, Means J, Chai F, Lamar M, Strauss G, Chiang W, Jarboe J, Schwartz B,Puzanov I: Efficacy in selected tumor types in a phase I study of the C-MET inhibitor ARQ 197 in combination with sorafenib. J Clin Oncol 2011, 29 (Suppl):3034.

75. Camacho L, Pant S, Saleh M, Abbadessa G, Kazakin J,Schwartz B, Bendell J: Phase lb results of c-MET inhibitor ARQ 197 in combination with gemcitabine in a cohort of patients (pts) with advanced breast, ovarian, and uterine tumors. J Clin Oncol 2011, 29(Suppl):3077.

76. Donehower R, Scardina A, Hill M, Bowman J, Newton R, Liu X, Scherle P, Wang Q, Diamond S, Boer J, Lee F, Gau T, Burris H, Bendell J, Jones S, Infante J: A phase I dose-escalation study of INCB028060, an inhibitor of c-MET receptor tyrosine kinase, in patients with advanced solid tumors. $J$ Clin Oncol 2011, 29(Suppl):3091.

77. Kuss JT, Muss HB, Hoen H, Case LD: Tamoxifen as initial endocrine therapy for metastatic breast cancer: long term follow-up of two Piedmont Oncology Association (POA) trials. Breast Cancer Res Treat 1997, 42:265-274.

78. Klijn JG, Beex LV, Mauriac L, van Zijl JA, Veyret C, Wildiers J, Jassem J, Piccart M, Burghouts J, Becquart D, Seynaeve C, Mignolet F, Duchateau L: Combined treatment with buserelin and tamoxifen in premenopausal metastatic breast cancer: a randomized study. J Nat/ Cancer Inst 2000, 92:903-911.

79. Howell A, Robertson JF, Abram P, Lichinitser MR, Elledge R, Bajetta E, Watanabe T, Morris C, Webster A, Dimery I, Osborne CK: Comparison of fulvestrant versus tamoxifen for the treatment of advanced breast cancer in postmenopausal women previously untreated with endocrine therapy: a multinational, double-blind, randomized trial. J Clin Oncol 2004, 22:1605-1613.

80. Thürlimann B, Hess D, Köberle D, Senn I, Ballabeni P, Pagani O, Perey L, Aebi S, Rochlitz C, Goldhirsch A: Anastrozole ('Arimidex') versus tamoxifen as firstline therapy in postmenopausal women with advanced breast cancer: results of the double-blind cross-over SAKK trial 21/95--a sub-study of the TARGET (Tamoxifen or 'Arimidex' Randomized Group Efficacy and Tolerability) trial. Breast Cancer Res Treat 2004, 85:247-254.

81. Mouridsen H, Gershanovich M, Sun Y, Pérez-Carrión R, Boni C, Monnier A Apffelstaedt J, Smith R, Sleeboom HP, Jänicke F, Pluzanska A, Dank M, Becquart D, Bapsy PP, Salminen E, Snyder R, Lassus M, Verbeek JA, Staffler B, Chaudri-Ross HA, Dugan M: Superior efficacy of letrozole versus tamoxifen as first-line therapy for postmenopausal women with advanced breast cancer: results of a phase III study of the International Letrozole Breast Cancer Group. J Clin Oncol 2001, 19:2596-2606.

82. Muss HB, Case LD, Atkins JN, Bearden JD 3rd, Cooper MR, Cruz JM, Jackson DV Jr., O'Rourke MA, Pavy MD, Powell BL, Richards F, Spurr CL, Eagle K, White DR: Tamoxifen versus high-dose oral medroxyprogesterone acetate as initial endocrine therapy for patients with metastatic breast cancer: A Piedmont Oncology Association Study. J Clin Oncol 1994, 12:1630-1638.

83. Seidman AD, Tiersten A, Hudis C, Gollub M, Barrett S, Yao TJ, Lepore J, Gilewski T, Currie V, Crown J, Hakes T, Baselga J, Sklarin N, Moynihan ME, Tong W, Egorin M, Kearns C, Spriggs D, Norton L: Phase II trial of paclitaxel by 3-hour infusion as initial and salvage chemotherapy for metastatic breast cancer. J Clin Oncol 1995, 13:2575-2581.

84. Oshaughnessy JA, Blum J, Moiseyenko V, Jones SE, Miles D, Bell D, Rosso R, Mauriac L, Osterwalder B, Burger HU, Laws S: Randomized, open-label, phase II trial of oral capecitabine (Xeloda) vs. a reference arm of intravenous CMF (cyclophosphamide, methotrexate and 5-fluorouracil) as first-line therapy for advanced/metastatic breast cancer. Ann Oncol 2001, 12:1247-1254

85. Carmichael J, Possinger K, Phillip P, Beykirch M, Kerr H, Walling J, Harris AL: Advanced breast cancer: a phase II trial with gemcitabine. J Clin Oncol 1995, 13:2731-2736.

86. ClinicalTrials.gov homepage [http://www.clinicaltrials.gov/].

\section{doi:10.1186/bcr3064}

Cite this article as: Gogineni K, DeMichele A: Current approaches to the management of Her2-negative metastatic breast cancer. Breast Cancer Research 2012, 14:205. 